Article

\title{
Apatite-Forming Ability of Flowable vs. Putty Formulations of Newly Developed Bioactive Glass-Containing Endodontic Cement
}

\author{
Naoki Edanami ${ }^{1, *}$, Razi Saifullah Ibn Belal ${ }^{1}$, Shoji Takenaka ${ }^{1}$, Kunihiko Yoshiba ${ }^{2}$, Nagako Yoshiba ${ }^{1}$, \\ Naoto Ohkura ${ }^{1}$, Shintaro Takahara ${ }^{1}$ and Yuichiro Noiri ${ }^{1}$
}

\section{check for}

updates

Citation: Edanami, N.; Ibn Belal R.S.; Takenaka, S.; Yoshiba, K.; Yoshiba, N.; Ohkura, N.; Takahara, S.; Noiri, Y. Apatite-Forming Ability of Flowable vs. Putty Formulations of Newly Developed Bioactive Glass-Containing Endodontic Cement. Appl. Sci. 2021, 11, 8969. https://doi.org/10.3390/ app11198969

Academic Editor: Luca Testarelli

Received: 11 August 2021

Accepted: 23 September 2021

Published: 26 September 2021

Publisher's Note: MDPI stays neutral with regard to jurisdictional claims in published maps and institutional affiliations.

Copyright: (c) 2021 by the authors. Licensee MDPI, Basel, Switzerland. This article is an open access article distributed under the terms and conditions of the Creative Commons Attribution (CC BY) license (https:/ / creativecommons.org/licenses/by/ $4.0 /)$.
1 Department of Oral Health Science, Division of Cariology, Operative dentistry and Endodontics, Graduate School of Medical and Dental Sciences, 2-5274 Gakkocho-dori, Chou-Ku, Niigata University, Niigata 951-8514, Japan; dr-razi@dent.niigata-u.ac.jp (R.S.I.B.); takenaka@dent.niigata-u.ac.jp (S.T.); nagako@dent.niigata-u.ac.jp (N.Y.); naotoo@umich.edu (N.O.); shintaroutaka.nc8@nuh.niigata-u.ac.jp (S.T.); noiri@dent.niigata-u.ac.jp (Y.N.)

2 Department of Oral Health and Welfare Science, Division of Oral Health and Welfare, Graduate School of Medical and Dental Sciences, Niigata University, Niigata 951-8514, Japan; yoshiba@dent.niigata-u.ac.jp

* Correspondence: edanami@dent.niigata-u.ac.jp; Tel.: +81-25-227-2865; Fax: +81-25-227-2864
Abstract: This study compared the apatite-forming ability (AFA) levels of flowable and putty formulations of Nishika Canal Sealer BG Multi (F-NBG and P-NBG, respectively) and attempted to clarify the cause of differences in the AFA levels of F-NBG and P-NBG. NBG samples were aged in simulated body fluid (SBF) or 1-, 5-, or 10-g/L bovine serum albumin-containing SBF (BSA$\mathrm{SBF}$ ) and analyzed in terms of their ultrastructures, elemental compositions, and Raman spectra to identify apatite formation. The phosphate ion consumption rates of NBG samples in the media were evaluated as an indicator of apatite growth. The original elemental composition, calcium ion release, and alkalizing ability levels of F-NBG and P-NBG were also evaluated. Apparent apatite formation was detected on all NBG samples except F-NBG aged in 10-g/L BSA-SBF. P-NBG consumed phosphate ions faster than F-NBG. As-prepared P-NBG showed more silicon elements on its surface than as-prepared F-NBG. P-NBG released more calcium ions than F-NBG, although their alkalizing ability levels did not differ statistically. In conclusion, the AFA of P-NBG was greater than that of F-NBG, probably because of the greater ability of P-NBG to expose silanol groups on the surface and release calcium ions.

Keywords: bioactive glass; Nishika Canal Sealer BG Multi; apatite forming ability; albumin; simulated body fluid

\section{Introduction}

Bioactive glass (BG) is a biomaterial with the ability to form bone-like carbonated apatite in the living body by interacting with phosphate ions in body fluids. BG was developed by Larry L. Hench in 1969 and has been used as a bone substitute. When BG is implanted in a bone defect, it bonds directly to bone via an apatite layer, without the interposition of connective tissues [1].

In recent years, BG-containing endodontic cements have been developed and marketed [2,3]. Previous studies have reported that these cements exhibit favorable biocompatibility $[4,5]$. In addition, these cements are thought to form an apatite layer at the interface with the dentin wall, dental pulp, or periodontal ligament [6]. The apatite layer formed between the material and dentin wall contributes to the prevention of bacterial leakage through the interface $[7,8]$. In addition, the apatite layer formed between the material and dental connective tissues acts as a substrate for the attachment, proliferation, and differentiation of stem cells, thereby supporting tissue healing [9]. 
Nishika Canal Sealer BG Multi (NBG) (Nippon Shika Yakuhin Co., Ltd., Yamaguchi, Japan) is a newly developed BG-containing cement indicated for both root canal fillings and vital pulp therapy. NBG comes in a semi-liquid, flowable consistency, although it can be prepared to a putty-like consistency by mixing the flowable NBG (F-NBG) with a designated BG-based powder (Nippon Shika Yakuhin Co., Ltd.). This putty-like consistency enables easier handling during vital pulp therapy.

Previous studies have reported that both F-NBG and putty-form NBG (P-NBG) induce apatite formation within 4 days of immersion in artificial body fluid (simulated body fluid [SBF]) with an ion concentration close to that of human blood serum [10,11]; however, the apatite-forming ability (AFA) levels of F-NBG and P-NBG have not been compared. Since AFA depends on the presence of BG, the AFA of P-NBG, which is prepared by adding BG-based powder to F-NBG, may be superior to that of F-NBG.

Most previous studies have used SBF to evaluate the AFA of biomaterials [12]; however, SBF is inorganic, whereas real body fluids contain non-negligible amounts of serum proteins [13]. Notably, albumin, the most abundant serum protein, is reported to suppress apatite formation on biomaterials $[14,15]$; therefore, AFA testing using albumin-containing SBF will provide more clinically relevant findings than testing using inorganic SBF.

The purpose of this study was to evaluate and compare the AFA levels of F-NBG and $\mathrm{P}-\mathrm{NBG}$ in SBF and SBF with various concentrations of bovine serum albumin (BSA). We also compared the original elemental composition, calcium ion release, and alkalizing ability levels of F-NBG and P-NBG in order to explore the reason for their different AFA values.

\section{Materials and Methods}

\subsection{Preparation of SBF and BSA-Containing SBF (BSA-SBF)}

SBF was prepared according to the protocol of Kokubo and Takadama [16]. Briefly, $8.035 \mathrm{~g}$ of NaCl, $0.355 \mathrm{~g}$ of $\mathrm{NaHCO}_{3}, 0.225 \mathrm{~g}$ of $\mathrm{KCl}, 0.231 \mathrm{~g}$ of $\mathrm{K}_{2} \mathrm{HPO}_{4} \cdot 3 \mathrm{H}_{2} \mathrm{O}, 0.311 \mathrm{~g}$ of $\mathrm{MgCl}_{2} \cdot 6 \mathrm{H}_{2} \mathrm{O}, 0.292 \mathrm{~g}$ of $\mathrm{CaCl}_{2}$, and $0.072 \mathrm{~g}$ of $\mathrm{Na}_{2} \mathrm{SO}_{4}$ were dissolved in $1000 \mathrm{~mL}$ of distilled water. The $\mathrm{pH}$ was adjusted to 7.4 by adding $6.118 \mathrm{~g}$ of tris-aminomethane and $\mathrm{HCl}$. BSA-SBF was prepared by adding BSA (Wako Pure Chemical Industries, Ltd., Osaka, Japan) to the SBF to bring the final concentration to 1,5 , or $10 \mathrm{~g} / \mathrm{L}$.

\subsection{AFA Test}

The composition of NBG is presented in Table 1. F-NBG was prepared by mixing pastes $A$ and $B$ at a ratio of 1:1. P-NBG was prepared by mixing the BG-based powder and F-NBG at a ratio of 6:10. The NBG samples ( $n=4$ each) were inserted into a polytetrafluoroethylene (PTFE) mold (internal diameter $2 \mathrm{~mm}$, length $5 \mathrm{~mm}$; one side sealed with $1 \mathrm{~mm}$ of gutta percha); immersed in $5 \mathrm{~mL}$ of SBF or 1-, 5-, or 10-g/L BSA-SBF; then stored at $37^{\circ} \mathrm{C}$ for 7 days, refreshing the media every 2 days. After aging the NBG samples, scanning electron microscopy (SEM) images, elemental composition information, and Raman spectra were obtained from the surfaces of the NBG samples. To obtain SEM images and elemental composition information, the samples were dried at room temperature and coated with a thin layer of gold using an ion sputtering device (IC-50; Shimadzu Corp., Kyoto, Japan). A representative area $(100.7 \times 75.5 \mu \mathrm{m})$ of each sample was then analyzed using an SEM equipped with wavelength-dispersive X-ray spectroscopy (EPMA1610; Shimadzu Corp.). The accelerating voltage was set at $15 \mathrm{kV}$. Raman spectra were obtained using a microRaman spectroscope (NRS-3100; JASCO, Tokyo, Japan) together with a microscope set at $100 \times$ magnification. A laser beam with an excitation wavelength of $532 \mathrm{~nm}$ and laser power of $7.4 \mathrm{~mW}$ was used. The charge-coupled device (CCD) detector was cooled down to a temperature of $-50{ }^{\circ} \mathrm{C}$. The measurements were carried out at 3 randomly selected points for each sample. Raman spectra of the as-prepared NBG samples were also measured as negative controls. 
Table 1. Materials used in this study.

\begin{tabular}{llll}
\hline Materials & Manufacturer & Lot No. & Composition \\
\hline $\begin{array}{l}\text { Flowable Nishika Canal Sealer } \\
\text { BG Multi (F-NBG) }\end{array}$ & $\begin{array}{l}\text { Nippon Shika } \\
\text { Yakuhin, Tokyo, Japan }\end{array}$ & L4D & $\begin{array}{l}\text { Paste A (50\%): Fatty acid, bismuth subcarbonate, } \\
\text { silicon dioxide } \\
\text { Paste B (50\%): Magnesium oxide, calcium silicate } \\
\text { glass (Bioactive glass), Silicon dioxide } \\
\text { Paste A (31\%): Fatty acid, bismuth subcarbonate, } \\
\text { Putty-form Nishika Canal } \\
\text { Sealer BG Multi (P-NBG) }\end{array}$ \\
& Nippon Shika & $\begin{array}{l}\text { Silicon dioxide } \\
\text { Paste B (31\%): Magnesium oxide, calcium silicate } \\
\text { glass (bioactive glass), silicon dioxide }\end{array}$ \\
& & L4D & $\begin{array}{l}\text { Powder (38\%): Calcium silicate glass (bioactive } \\
\text { glass), calcium hydroxide }\end{array}$ \\
\hline
\end{tabular}

\subsection{Evaluation of Phosphate Ion Consumption by F-NBG and P-NBG in SBF and BSA-SBF}

PTFE tubes filled with NBG samples were prepared as described in Section 2.2 above and immersed in $1 \mathrm{~mL}$ of SBF or $1-, 5-$, or $10-\mathrm{g} / \mathrm{L} \mathrm{BSA-SBF}$ ( $n=6$ each). At 1,3 , and 7 days $(24,72$, and $168 \mathrm{~h}), 100 \mu \mathrm{L}$ samples were collected from the media and the phosphate ion concentration was measured using a kit (DPM2-PO4-C; Kyoritsu Chemical-Check Lab Corp., Tokyo, Japan) based on the molybdenum blue method [17]. The baseline phosphate ion concentration of the media was also evaluated. A standard curve was prepared using a phosphate ion standard solution (Wako Pure Chemical Industries, Ltd.), the correlation coefficient of which was 0.997 . The phosphate ion concentrations of F-NBG and P-NBG soaking in media were statistically compared at each time point using an unpaired $t$-test. Differences with $p$ values $<0.05$ were considered statistically significant.

\subsection{Surface Characterization of As-Prepared NBG Samples}

PTFE tubes filled with NBG samples were prepared as described in Section 2.2 above and stored at $37{ }^{\circ} \mathrm{C}$ at $100 \%$ humidity for $24 \mathrm{~h}$ to allow the materials to harden ( $n=6$ each). A randomly selected area $(100.7 \times 75.5 \mu \mathrm{m})$ of each sample was analyzed using the EPMA1610, then the SEM images and average elemental composition of six samples were taken. Differences in the elemental composition were tested using an unpaired $t$-test, with $p<0.05$ considered statistically significant.

\subsection{Analysis of Calcium Ion Release and Alkalizing Ability}

PTFE tubes filled with NBG samples were prepared as described in Section 2.2 above, immersed in $5 \mathrm{~mL}$ of distilled water, then stored at $37^{\circ} \mathrm{C}(n=6$ each). After 7 days, the calcium ion concentration and $\mathrm{pH}$ of the soaking water were evaluated using a calcium ion meter (LAQUAtwin Ca-11; Horiba, Kyoto, Japan) and a $\mathrm{pH}$ meter (LAQUAtwin pH-22B; Horiba), respectively. The data were analyzed using an unpaired $t$-test, with $p$ values $<0.05$ considered statistically significant.

\section{Results}

\subsection{AFA}

The surface of each NBG sample was completely covered by apatite-like spherulites after aging in SBF or 1- or 5-g/L BSA-SBF (Figure 1a-c,e-g). In 10-g/L BSA-SBF, apatitelike spherulites were observed to cover the surface of P-NBG, although almost none were observed on the F-NBG (Figure 1d,h). The aged NBG samples exhibited calcium, oxygen, carbon, and phosphorus elements on the surface as major constituents (Figure 1i,j), although only the F-NBG aged in 10-g/L BSA-SBF exhibited bismuth elements on the surface (Figure 1i). Raman bands attributable to apatite (v1 $\mathrm{PO}_{4}{ }^{3-}$ band at $960 \mathrm{~cm}^{-1}$ ) were detected on all aged NBG samples, although the band observed on the F-NBG aged in 10-g/L BSA-SBF was weak (Figure 1k,l). 

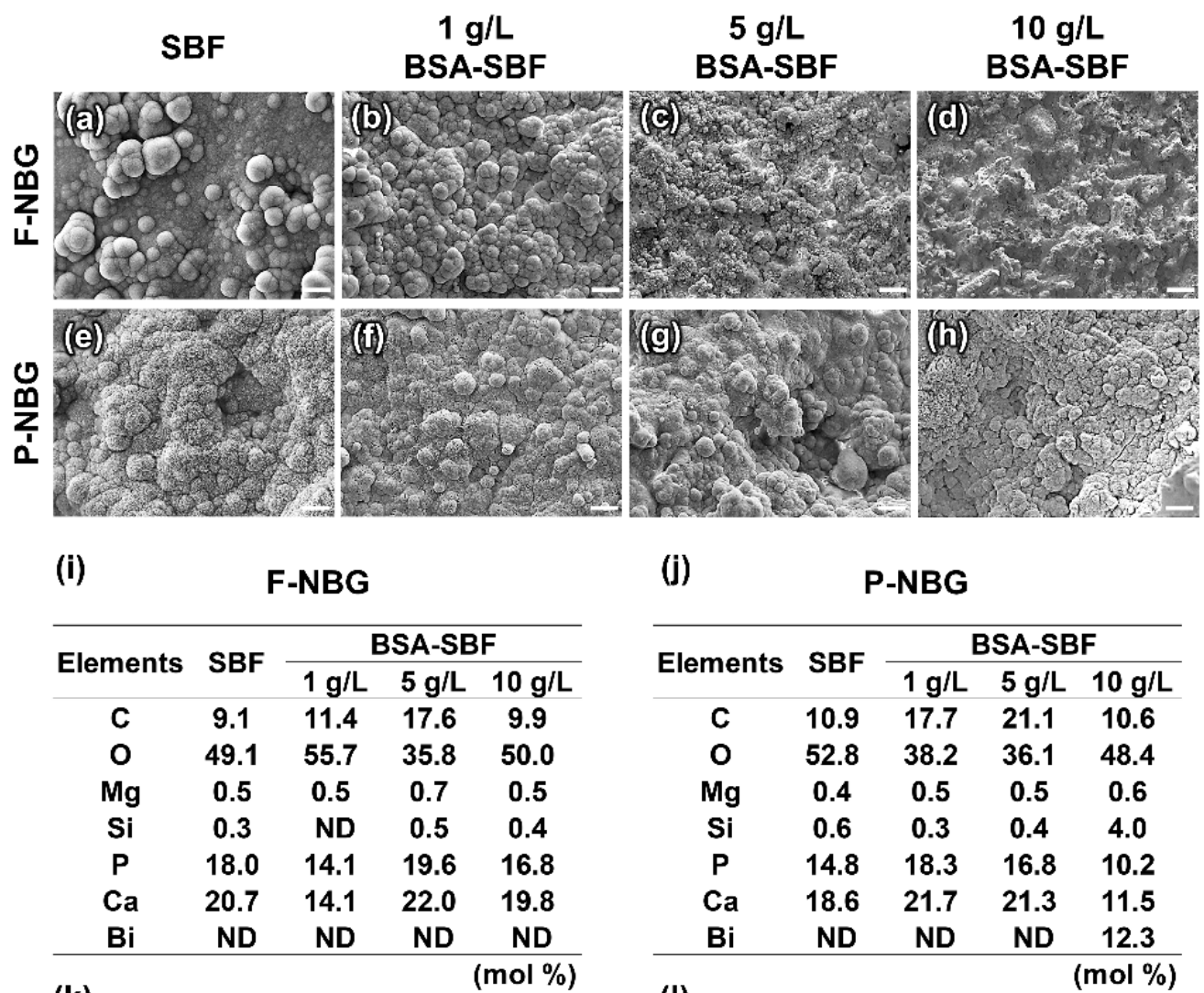

(j)

P-NBG

(k)

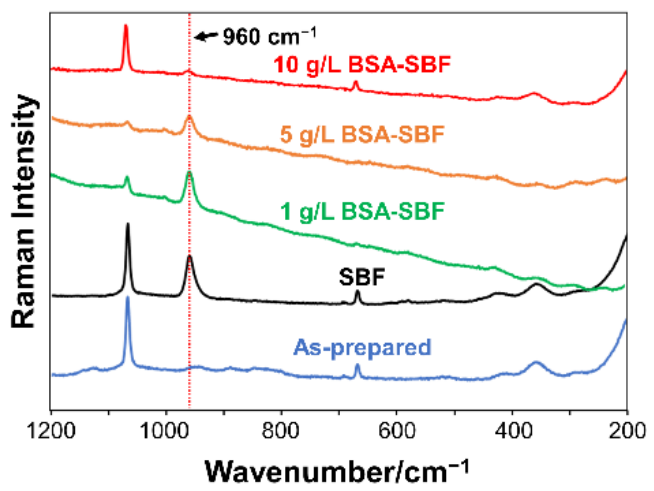

\begin{tabular}{ccccc}
\hline \multirow{2}{*}{ Elements } & \multirow{2}{*}{$\mathrm{SBF}$} & \multicolumn{3}{c}{ BSA-SBF } \\
\cline { 3 - 5 } & & $\mathbf{g} / \mathrm{L}$ & $\mathbf{5} \mathrm{g} / \mathrm{L}$ & $\mathbf{1 0} \mathrm{g} / \mathrm{L}$ \\
$\mathrm{C}$ & 10.9 & 17.7 & 21.1 & 10.6 \\
$\mathrm{O}$ & 52.8 & 38.2 & 36.1 & 48.4 \\
$\mathrm{Mg}$ & 0.4 & 0.5 & 0.5 & 0.6 \\
$\mathrm{Si}$ & 0.6 & 0.3 & 0.4 & 4.0 \\
$\mathrm{P}$ & 14.8 & 18.3 & 16.8 & 10.2 \\
$\mathrm{Ca}$ & 18.6 & 21.7 & 21.3 & 11.5 \\
$\mathrm{Bi}$ & $\mathrm{ND}$ & $\mathrm{ND}$ & $\mathrm{ND}$ & 12.3 \\
\hline \multirow{2}{*}{} & & \multicolumn{3}{c}{ (mol \%) }
\end{tabular}

P-NBG

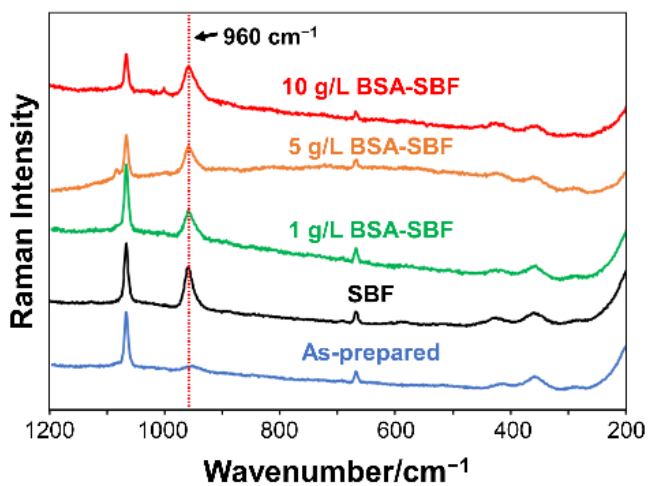

Figure 1. Representative ultrastructure (a-h), elemental composition $(\mathbf{i}, \mathbf{j})$, and Raman spectra $(\mathbf{k}, \mathbf{l})$ of the surface of flowable and putty-form Nishika Canal Sealer BG Multi (F-NBG and P-NBG) aged in simulated body fluid (SBF) or 1-, 5-, or 10-g/L bovine serum albumin-containing SBF (BSA-SBF). C: carbon; O: oxygen; Mg: magnesium; Si: silicon; P: phosphorus; Ca: calcium; Bi: bismuth. ND: Not detected. Scale $=10 \mu \mathrm{m}$.

\subsection{Phosphate Ion Consumption by F-NBG and P-NBG in SBF and BSA-SBF}

Time-course changes of the phosphate ion concentration in the SBF and BSA-SBF after soaking of the NBG samples are shown in Figure 2. In all tested media, P-NBG consumed phosphate ions faster than F-NBG. The baseline phosphate ion concentration became smaller with increases in the BSA concentration in the media.

\subsection{Surface Characteristics of As-Prepared NBG Samples}

In SEM images, BG-like crystals with an irregular structure were observed on both types of NBG. The density of crystals on P-NBG appeared to be greater than on F-NBG (Figure 3a-d). Significantly greater amounts of silicon and oxygen elements and signifi- 
cantly smaller amounts of carbon and magnesium elements were detected on P-NBG than on F-NBG (Figure 3e).

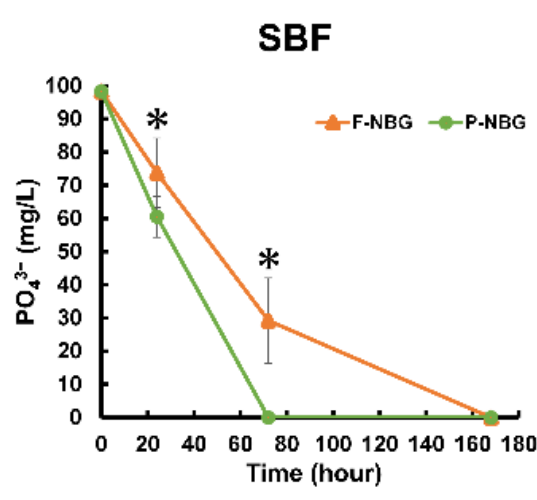

$5 \mathrm{~g} / \mathrm{L}$

BSA-SBF

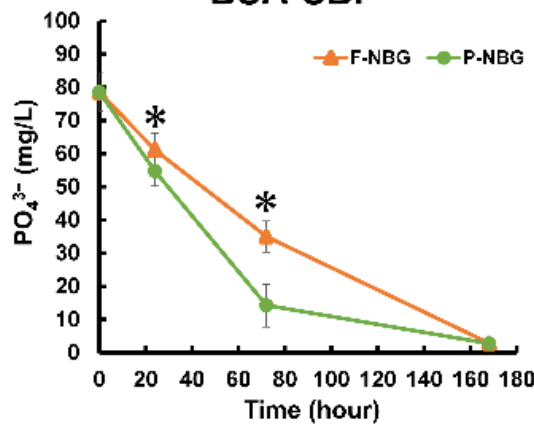

$1 \mathrm{~g} / \mathrm{L}$

\section{BSA-SBF}

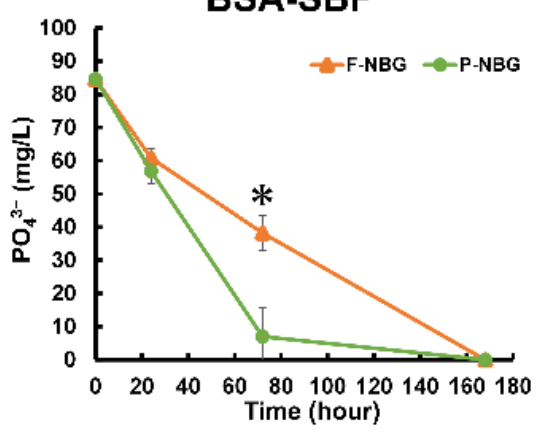

$10 \mathrm{~g} / \mathrm{L}$

BSA-SBF

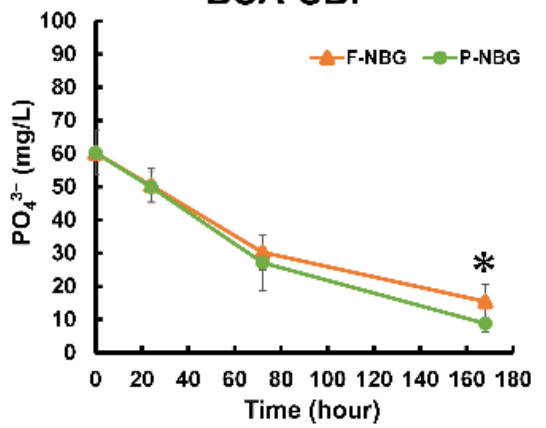

Figure 2. Phosphate ion $\left(\mathrm{PO}_{4}{ }^{3-}\right)$ concentration in simulated body fluid (SBF) or 1-, 5-, or 10-g/L bovine serum albumin-containing SBF (BSA-SBF) after the immersion of flowable and putty-form Nishika Canal Sealer BG Multi (F-NBG and P-NBG). Asterisks indicate $p<0.05$ (unpaired $t$-test, $n=6$ ).

\section{F-NBG}

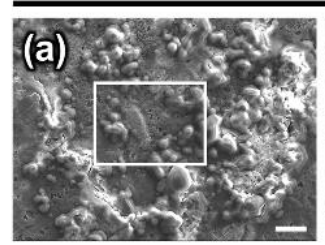

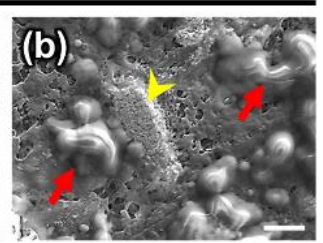

P-NBG

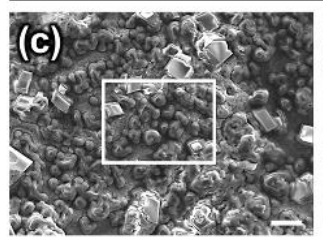

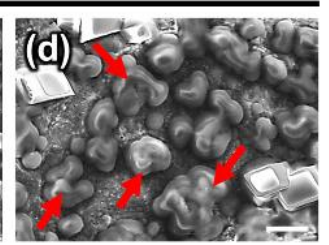

(e)

\begin{tabular}{cccccccc}
\hline & $\mathrm{C}$ & $\mathrm{O}$ & $\mathrm{Mg}$ & $\mathrm{Si}$ & $\mathrm{P}$ & $\mathrm{Ca}$ & $\mathrm{Bi}$ \\
\hline F-NBG & $\mathbf{6 7 . 9 8}(3.31)$ & $21.23(3.81)$ & $1.44(0.24)$ & $2.18(1.45)$ & $1.36(0.29)$ & $4.32(0.85)$ & $0.91(0.49)$ \\
P-NBG & $57.89(8.64)$ & $27.32(3.89)$ & $0.68(0.28)$ & $4.98(1.64)$ & $1.54(0.62)$ & $6.34(2.48)$ & $0.74(0.44)$ \\
$p$ & $0.024^{*}$ & $0.021^{*}$ & $0.00048^{*}$ & $0.011^{*}$ & 0.55 & 0.089 & 0.53 \\
\hline \multicolumn{1}{r}{} & & & & & & $(\mathrm{mol} \%)$
\end{tabular}

Figure 3. Representative ultrastructures (a-d) and average elemental compositions (e) of the surface of as-prepared flowable and putty-form Nishika Canal Sealer BG Multi (F-NBG and P-NBG). $(\mathbf{b}, \mathbf{d})$ Higher-magnification views of boxed regions in $(\mathbf{a}, \mathbf{c})$. Arrows in $(\mathbf{b}, \mathbf{d})$ indicate bioactive glasslike irregular shaped crystals. Arrowheads in (b) indicate a bismuth subcarbonate-like rod-shaped crystal. Data for elemental composition are shown as the mean (SD) \% of six samples. Asterisks indicate $p<0.05$ (unpaired $t$-test, $n=6$ ). C: carbon; O: oxygen; Mg: magnesium; Si: silicon; P: phosphorus; Ca: calcium; Bi: bismuth. Scale $=10 \mu \mathrm{m}(\mathbf{a}, \mathbf{c}), 5 \mu \mathrm{m}(\mathbf{b}, \mathbf{d})$. 


\subsection{Calcium Ion Release and Alkalizing Ability}

P-NBG increased the calcium ion concentration of its soaking water more than the F-NBG did (Figure 4a). Both F-NBG and P-NBG alkalized the soaking water and pH levels did not differ statistically between materials (Figure $4 b$ ).
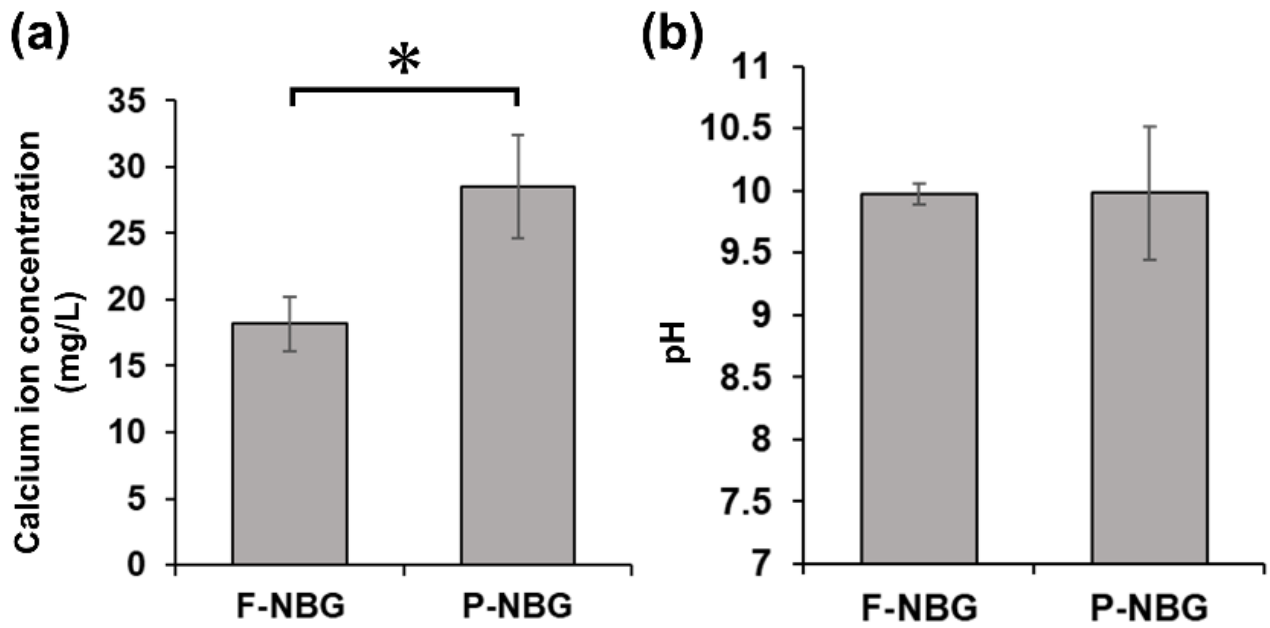

Figure 4. Calcium ion concentrations (a) and pH levels (b) of distilled water after immersion of flowable and putty-form Nishika Canal Sealer BG Multi (F-NBG and P-NBG). Asterisk indicates $p<0.05$ (unpaired $t$-test, $n=6$ ).

\section{Discussion}

Previous studies have reported that the bone-like apatite formed on biomaterials exhibits a spherical shape [18]; calcium-, phosphorus-, carbon-, and oxygen-rich elemental composition [19]; and a v1 $\mathrm{PO}_{4}{ }^{3-}$ Raman band at $960 \mathrm{~cm}^{-1}$ [20]. In the present study, aged NBG samples, except for F-NBG aged in 10-g/L BSA-SBF, displayed surfaces covered by apatite-like spherical precipitates composed mainly of calcium, phosphorus, carbon, and oxygen elements, showing clear v1 $\mathrm{PO}_{4}{ }^{3-}$ Raman bands at $960 \mathrm{~cm}^{-1}$ (Figure 1). In contrast, the surface of F-NBG aged in 10-g/L BSA-SBF exhibited few spherical precipitates, bismuth elements originating from the NBG content, and a weak Raman band at $960 \mathrm{~cm}^{-1}$ (Figure 1). These findings indicated that both F-NBG and P-NBG formed apatite in all tested media, although only a scant amount of apatite was formed on F-NBG in 10-g/L BSA-SBF. The positive AFA values of NBGs in SBF $[3,10,11]$ and the negative effects of BSA on apatite formation $[14,15]$ are consistent with previous reports.

Next, we further evaluated the phosphate ion consumption rate after immersing NBG samples in SBF and BSA-SBF, as this reflects apatite growth on NBGs [21,22]. The rates of phosphate ion consumption of P-NBG were greater than that of F-NBG in all tested media (Figure 2), which indicated faster apatite growth on P-NBG than on F-NBG. Based on these findings, it can be concluded that P-NBG has greater AFA than F-NBG. The null hypothesis that the AFA of P-NBG does not differ from that of F-NBG was, thus, rejected.

The greater AFA of P-NBG may be associated with its greater capacity to expose apatite nucleation sites on the surface. In the present study, BG-like crystals appeared on the as-prepared P-NBG at a higher density than on the as-prepared F-NBG. In addition, the surface elemental composition of the as-prepared P-NBG was silicon- and oxygenrich but carbon- and magnesium-deficient compared with that of as-prepared F-NBG (Figure 3). This result indicated that more $\mathrm{BG}\left(\mathrm{SiO}_{2}-\mathrm{Na}_{2} \mathrm{O}-\mathrm{CaO}-\mathrm{P}_{2} \mathrm{O}_{5}\right.$ glass) was exposed on the as-prepared P-NBG than on the as-prepared F-NBG. The BG partially degrades after contact with body fluids and negatively charged silanol groups are formed on the surface. The silanol groups then act as nucleation sites of apatite, binding calcium ions in the surrounding environment [23]. It is, therefore, reasonable to draw the conclusion that 
silanol groups, acting as apatite nucleation sites, were more abundant on P-NBG than on F-NBG and enabled faster apatite formation on P-NBG.

In the present study, distilled water was used to evaluate the calcium ion release and alkalizing ability of NBGs. In physiological solutions, NBGs consume calcium and hydroxyl ions for apatite formation, which obscures the calcium ion release and alkalizing effect of NBGs; therefore, distilled water is optimal for this purpose.

Apatite growth on biomaterials is accelerated by increases in the calcium ion concentration and $\mathrm{pH}$ of the surrounding environment [24]. We found that the calcium ion release from P-NBG was significantly greater than that from F-NBG, whereas no significant difference in alkalizing ability was observed between NBGs (Figure 4). The greater calcium ion release may also be responsible for the greater AFA of P-NBG.

Albumin inhibits apatite formation by obstructing apatite nucleation sites [25]. The sparse formation of apatite on F-NBG aged in 10-g/L BSA-SBF may have resulted from the almost complete blockage of apatite nucleation sites by albumin. In addition, it has been reported that albumin binds calcium and phosphate ions in body fluids and reduces the number of ions available for apatite nucleation [26]. Consistent with the results of a previous study, free phosphate ions in SBF decreased with the addition of BSA in a concentration-dependent manner in the present study (Figure 2). This effect of albumin may have also caused the small amount of apatite formation on F-NBG aged in 10-g/L BSA-SBF.

During root canal therapy or vital pulp therapy, NBGs come into contact with the interstitial tissue fluid in the dental pulp or periodontal ligament. The interstitial tissue fluid contains albumin at a concentration of around 10-g/L $[27,28]$. Considering the apparent apatite formation on P-NBG and the limited apatite formation on F-NBG in 10-g/L BSASBF, possibly only P-NBG produces sufficient apatite in clinical settings to prevent bacterial leakage [7] and support tissue healing [9]. A recent study also suggested that the AFA of F-NBG may be clinically insufficient, showing no apatite precipitation on F-NBG in rat subcutaneous tissue [29].

P-NBG was specifically designed for vital pulp therapy. At present, calcium silicate cements are the gold standard for vital pulp therapy because they are highly biocompatible $[30,31]$ and associated with favorable clinical outcomes [32]. One study reported that F-NBG induced a favorable quality of reparative dentin formation in rat molars compared with a representative calcium silicate cement, namely ProRoot MTA [10]. Although the clinical performance of P-NBG has not yet been evaluated, this study has shown that the AFA level - a key feature of vital pulp therapy agents — of P-NBG was superior to that of F-NBG; therefore, P-NBG may be a good option for vital pulp therapy.

A limitation of this study was that the AFA levels of NBGs were compared only in vitro. Unlike the media used in this study, real body fluids contain various proteins in addition to albumin. The minor serum proteins have been reported to have positive [33,34] or negative effects [35] on apatite formation. Moreover, Wang et al. reported that lysozyme, a serum protein, decreased the inhibitory effect of albumin on apatite formation [36]. In addition, inflammatory reactions negatively affect apatite formation by reducing the local $\mathrm{pH}$ [37]; therefore, the in vivo AFA levels of NBGs may slightly differ from the in vitro AFA levels. As such, the in vivo AFA levels of NBGs should be compared in a future study.

The present study has demonstrated that BG-based powder not only changes the consistency of NBG but also improves the AFA level. Moreover, a previous study reported that BG-based powder did not affect the solubility or cytocompatibility of NBG [11]. Based on these findings, it can be speculated that BG-based powder may be helpful in changing the consistency of other BG-based or non-BG-based endodontic materials, improving the AFA level. This possibility should be examined in future studies.

\section{Conclusions}

P-NBG, but not F-NBG, induced apparent apatite formation in 10-g/L BSA-SBF, overcoming the inhibitory effect of albumin on apatite formation. P-NBG induced faster 
growth of apatite in SBF and BSA-SBF compared with F-NBG. The greater AFA level of P-NBG than that of F-NBG may be attributable to the greater ability of P-NBG to expose apatite nucleation sites on the surface and release calcium ions.

Author Contributions: Conceptualization, N.E.; methodology, N.E., S.T. (Shoji Takenaka) and K.Y.; investigation, N.E., R.S.I.B., K.Y. and S.T. (Shintaro Takahara); data curation, N.Y. and N.O.; writingoriginal draft preparation, N.E. and R.S.I.B.; writing-review and editing, S.T. (Shoji Takenaka), K.Y., N.Y., N.O. and Y.N.; supervision, K.Y. and Y.N.; project administration, N.E. All authors have read and agreed to the published version of the manuscript.

Funding: This research was funded by Grants-in-Aid for Scientific Research from the Japan Society for the Promotion of Science (21k16966).

Institutional Review Board Statement: Not applicable.

Informed Consent Statement: Not applicable.

Data Availability Statement: Data sets used during the study are available from the corresponding author on reasonable request.

Acknowledgments: This work was the result of using research equipment in CCRF, Niigata University. We thank Ayako Ikarashi for providing technical support. This work was the result of using research equipment shared in the MEXT Project to promote public utilization of advanced research infrastructure (program for supporting the introduction of the new sharing system) at Niigata University, grant number JPMXS0421100221. The authors would like to thank Nippon Shika Yakuhin Co., Ltd., for providing Nishika Canal Sealer BG Multi.

Conflicts of Interest: The authors declare no conflict of interest.

\section{References}

1. Kokubo, T.; Yamaguchi, S. Simulated body fluid and the novel bioactive materials derived from it. J. Biomed. Mater. Res. Part A 2019, 107, 968-977. [CrossRef]

2. Hoikkala, N.-P.J.; Siekkinen, M.; Hupa, L.; Vallittu, P.K. Behaviour of different bioactive glasses incorporated in polydimethylsiloxane endodontic sealer. Dent. Mater. 2021, 37, 321-327. [CrossRef]

3. Bin Jo, S.; Kim, H.K.; Lee, H.N.; Kim, Y.-J.; Patel, K.D.; Knowles, J.C.; Lee, J.-H.; Song, M. Physical Properties and Biofunctionalities of Bioactive Root Canal Sealers In Vitro. Nanomaterials 2020, 10, 1750. [CrossRef]

4. Santos, J.M.; Pereira, S.; Sequeira, D.B.; Messias, A.L.; Martins, J.B.; Cunha, H.; Palma, P.J.; Santos, A.C. Biocompatibility of a bioceramic silicone-based sealer in subcutaneous tissue. J. Oral Sci. 2019, 61, 171-177. [CrossRef] [PubMed]

5. Mena-Álvarez, J.; Rico-Romano, C.; Gutiérrez-Ortega, C.; Arias-Sanz, P.; Castro-Urda, J. A Comparative Study of Biocompatibility in Rat Connective Tissue of a New Mineral Trioxide Compound (Theracal) versus MTA and a Bioactive G3 Glass. J. Clin. Med. 2021, 10, 2536. [CrossRef] [PubMed]

6. Skallevold, H.E.; Rokaya, D.; Khurshid, Z.; Zafar, M.S. Bioactive Glass Applications in Dentistry. Int. J. Mol. Sci. 2019, 20, 5960. [CrossRef]

7. Do Carmo, S.S.; Néspoli, F.F.P.; Bachmann, L.; Miranda, C.E.S.; Castro-Raucci, L.M.S.; Oliveira, I.R.; Raucci-Neto, W. Influence of early mineral deposits of silicate- and aluminate-based cements on push-out bond strength to root dentine. Int. Endod. J. 2018, 51, 92-101. [CrossRef]

8. Martin, R.L.; Monticelli, F.; Brackett, W.W.; Loushine, R.J.; Rockman, R.A.; Ferrari, M.; Pashley, D.H.; Tay, F.R. Sealing Properties of Mineral Trioxide Aggregate Orthograde Apical Plugs and Root Fillings in an In Vitro Apexification Model. J. Endod. 2007, 33, 272-275. [CrossRef]

9. Gandolfi, M.G.; Ciapetti, G.; Taddei, P.; Perut, F.; Tinti, A.; Cardoso, M.V.; Van Meerbeek, B.; Prati, C. Apatite formation on bioactive calcium-silicate cements for dentistry affects surface topography and human marrow stromal cells proliferation. Dent. Mater. 2010, 26, 974-992. [CrossRef]

10. Hanada, K.; Morotomi, T.; Washio, A.; Yada, N.; Matsuo, K.; Teshima, H.; Yokota, K.; Kitamura, C. In vitro and in vivo effects of a novel bioactive glass-based cement used as a direct pulp capping agent. J. Biomed. Mater. Res. Part B Appl. Biomater. 2019, 107, 161-168. [CrossRef]

11. Murata, K.; Washio, A.; Morotomi, T.; Rojasawasthien, T.; Kokabu, S.; Kitamura, C. Physicochemical Properties, Cytocompatibility, and Biocompatibility of a Bioactive Glass Based Retrograde Filling Material. Nanomaterials 2021, 11, 1828. [CrossRef]

12. Bohner, M.; Lemaitre, J. Can bioactivity be tested in vitro with SBF solution? Biomaterials 2009, 30, 2175-2179. [CrossRef] [PubMed]

13. Dory, L.; Sloop, C.H.; Roheim, P.S. Interstitial fluid (peripheral lymph) lipoproteins. Methods Enzymol. 1986, 129, 660-678. [CrossRef] [PubMed] 
14. Zhao, W.; Lemaître, J.; Bowen, P. A comparative study of simulated body fluids in the presence of proteins. Acta Biomater. 2017, 53, 506-514. [CrossRef]

15. Mavropoulos, E.; Costa, A.M.; Costa, L.T.; Achete, C.A.; Mello, A.; Granjeiro, J.M.; Rossi, A.M. Adsorption and bioactivity studies of albumin onto hydroxyapatite surface. Colloids Surf. B Biointerfaces 2011, 83, 1-9. [CrossRef] [PubMed]

16. Kokubo, T.; Takadama, H. How useful is SBF in predicting in vivo bone bioactivity? Biomaterials 2006, 27, 2907-2915. [CrossRef]

17. Sjösten, A.; Blomqvist, S. Influence of phosphate concentration and reaction temperature when using the molybdenum blue method for determination of phosphate in water. Water Res. 1997, 31, 1818-1823. [CrossRef]

18. Han, L.; Okiji, T.; Okawa, S. Morphological and chemical analysis of different precipitates on mineral trioxide aggregate immersed in different fluids. Dent. Mater. J. 2010, 29, 512-517. [CrossRef] [PubMed]

19. Kim, H.-M.; Himeno, T.; Kokubo, T.; Nakamura, T. Process and kinetics of bonelike apatite formation on sintered hydroxyapatite in a simulated body fluid. Biomaterials 2005, 26, 4366-4373. [CrossRef]

20. Gandolfi, M.G.; Taddei, P.; Tinti, A.; Prati, C. Apatite-forming ability (bioactivity) of ProRoot MTA. Int. Endod. J. 2010, 43, 917-929. [CrossRef]

21. Prakash, K.H.; Kumar, R.; Yu, S.C.; Khor, K.A.; Cheang, P. On the Kinetics of Apatite Growth on Substrates under Physiological Conditions. Langmuir 2006, 22, 269-276. [CrossRef]

22. Tsuru, K.; Kubo, M.; Hayakawa, S.; Ohtsuki, C.; Osaka, A. Kinetics of Apatite Deposition of Silica Gel Dependent on the Inorganic Ion Composition of Simulated Body Fluids. J. Ceram. Soc. Jpn. 2001, 109, 412-418. [CrossRef]

23. Washio, A.; Morotomi, T.; Yoshii, S.; Kitamura, C. Bioactive Glass-Based Endodontic Sealer as a Promising Root Canal Filling Material without Semisolid Core Materials. Materials 2019, 12, 3967. [CrossRef]

24. Lu, X.; Leng, Y. Theoretical analysis of calcium phosphate precipitation in simulated body fluid. Biomaterials 2005, 26, 1097-1108. [CrossRef] [PubMed]

25. D’Elia, N.L.; Gravina, N.; Ruso, J.M.; Marco-Brown, J.L.; Sieben, J.M.; Messina, P.V. Albumin-mediated deposition of bone-like apatite onto nano-sized surfaces: Effect of surface reactivity and interfacial hydration. J. Colloid Interface Sci. 2017, 494, 345-354. [CrossRef] [PubMed]

26. Wang, K.; Leng, Y.; Lu, X.; Ren, F.; Ge, X.; Ding, Y. Theoretical analysis of protein effects on calcium phosphate precipitation in simulated body fluid. CrystEngComm 2012, 14, 5870-5878. [CrossRef]

27. Haaverstad, R.; Romslo, I.; Myhre, H.O. The concentration of high molecular weight compounds in interstitial tissue fluid: A study in patients with post-reconstructive leg oedema. Eur. J. Vasc. Endovasc. Surg. 1997, 13, 355-360. [CrossRef]

28. Ellmerer, M.; Schaupp, L.; Brunner, G.A.; Sendlhofer, G.; Wutte, A.; Wach, P.; Pieber, T.R. Measurement of interstitial albumin in human skeletal muscle and adipose tissue by open-flow microperfusion. Am. J. Physiol.-Endocrinol. Metab. 2000, 278, E352-E356. [CrossRef]

29. Ibn Belal, R.S.; Edanami, N.; Yoshiba, K.; Yoshiba, N.; Ohkura, N.; Takenaka, S.; Noiri, Y. Comparison of calcium and hydroxyl ion release ability and in vivo apatite-forming ability of three bioceramic-containing root canal sealers. Clin. Oral Investig. 2021 [CrossRef]

30. Santos, J.M.; Coelho, C.M.; Sequeira, D.B.; Marques, J.A.; Pereira, J.F.; Sousa, V.; Palma, P.J.; Santos, A.C. Subcutaneous Implantation Assessment of New Calcium-Silicate Based Sealer for Warm Obturation. Biomedicines 2021, 9, 24. [CrossRef]

31. Bósio, C.C.; Felippe, G.S.; Bortoluzzi, E.A.; Felippe, M.C.S.; Felippe, W.T.; Rivero, E.R.C. Subcutaneous connective tissue reactions to iRoot SP, mineral trioxide aggregate (MTA) Fillapex, DiaRoot BioAggregate and MTA. Int. Endod. J. 2014, 47, 667-674. [CrossRef]

32. Cushley, S.; Duncan, H.F.; Lappin, M.J.; Chua, P.; Elamin, A.D.; Clarke, M.; El-Karim, I.A. Efficacy of direct pulp capping for management of cariously exposed pulps in permanent teeth: A systematic review and meta-analysis. Int. Endod. J. 2021, 54, 556-571. [CrossRef] [PubMed]

33. Tagaya, M.; Ikoma, T.; Takeguchi, M.; Hanagata, N.; Tanaka, J. Interfacial Serum Protein Effect on Biological Apatite Growth. J. Phys. Chem. C 2011, 115, 22523-22533. [CrossRef]

34. Termine, J.D.; Kleinman, H.K.; Whitson, S.W.; Conn, K.M.; McGarvey, M.L.; Martin, G.R. Osteonectin, a bone-specific protein linking mineral to collagen. Cell 1981, 26, 99-105. [CrossRef]

35. Doi, Y.; Okuda, R.; Takezawa, Y.; Shibata, S.; Moriwaki, Y.; Wakamatsu, N.; Shimizu, N.; Moriyama, K.; Shimokawa, H. Osteonectin inhibitingde novo formation of apatite in the presence of collagen. Calcif. Tissue Int. 1989, 44, 200-208. [CrossRef]

36. Wang, K.; Leng, Y.; Lu, X.; Ren, F. Calcium phosphate bioceramics induce mineralization modulated by proteins. Mater. Sci. Eng. C Mater. Biol. Appl. 2013, 33, 3245-3255. [CrossRef] [PubMed]

37. Namazikhah, M.S.; Nekoofar, M.H.; Sheykhrezae, M.S.; Salariyeh, S.; Hayes, S.J.; Bryant, S.T.; Mohammadi, M.M.; Dummer, P.M.H. The effect of $\mathrm{pH}$ on surface hardness and microstructure of mineral trioxide aggregate. Int. Endod. J. 2008, 41, 108-116. [CrossRef] [PubMed] 